\title{
Redescription of Argulus japonicus Thiele, 1900 (Crustacea: Branchiura) an ectoparasite of gold fish (Carrassius auratus) with notes regarding its pathology .
}

\author{
Fawzia, H., Toulah ${ }^{1}$
}

\begin{abstract}
Carassius auratus (Actinopterygii: Cyprinidae), living in an aquarium with symptoms such as abnormal swimming and lack of appetite were examined for ectoparasites. The parasites collected from the skin and fins of infected fish were identified as Argulus japonicus, redescribed and illustrated. Pathological changes due to infection was discussed.
\end{abstract}

Keywords: An ectoparasite of goldfish, parasitic crustacea, Argulus, Pathology of Argulus.

\section{INTRODUCTION}

Argulus Miiller, 1785 (Branchiura) is an important genus containing some 120 described species that are predominantly parasites of fishes. Together these ectoparasites inhabit both marine and fresh waters, and globally Argulus has a cosmopolitan distribution (Benz. et al., 1995).

Many species of Argulus have been recorded from Africa, Europe. Asia, Australia, and North,Central and South America (Heegaard, 1962; Yamaguti, 1963; Fryer, 1968; Hewitt and Hine, 1972and Byrnes, 1985). Twenty-three species were recognized in marine and fresh waters of the United States by Cressey (1972).

Argulus japonicus Thiele, 1900 is a widespread ectoparasite of many freshwater fish species from Japan, China, Europe, America and Africa (Fryer, 1960). Pilgrim (1967) recorded A.japonicus in New Zealand from housed goldfish recently imported from South East Asia. Kruger et al.(1983) stated that A.japonicus which was introduced from the Far east to southern Africa on carp and / or gold fish, is now an omnipresent parasite of both carp and native fish; species of Barbus and Labeo, Clarias gariepinus and occasionally cichlid fish. In Israel A. japonicus have been considered as a serious pest of farmed carp for several years (Landsberg, 1989). It also became a frequent parasite of fish in natural habitats, particularly of the Jordan system (Papema, 1991).
Argulus coregoni had been found on brown trout (Salmo trutta) in the River Clyde in Scotland and A.foliaceus on brown trout, as well as stickleback (Gasterosteus aculeatus), roach (Rutilus rutilus), perch (Perca fluviatilis), carp (Cyprinus carpio), tench (Tinca tinca), pike (Esox lucius) and bream (Abramis brama) (Campbell, 1971).

The disease Argulosis, is one of the most readily identified diseases of finfish. The behaviour of the fish is often the first indication of an infection. The first behavioural change is observed as fish repeatedly rub its flanks and / or fins against the substrate or other submerged objects. The direct effects of this parasite on its fish host depend on the intensity of the infection level and the size of the fish host (Richards, 1977; and Kabata, 1985).

As well as the damage and stress caused by Argulus itself, one of main worries for fish producers is the associated secondary infections that can result from infection with parasites. Cusack and Cone (1986) stated that Argulus species are notorious for causing mortality in captive fish populations either directly via their feeding or indirectly by opening portals for the invasion of pathogens such as viruses, bacteria and fungi .

\section{MATERIALS AND METHODS}

Five specimens of fish louse had been found living in an aquarium fish taken from a local pet shop, which had housed godfish, Carassius auratus. Parasites were taken from their host fish, collected from around the operculum and fins, fixed in $10 \%$ formalin, and later transferred to $70 \%$ ethanol. Unstained and stained (Lignin pink or chlorazol black) specimens were examined using standard bright field microscope. Specimens to be dissected were first cleared in $\mathrm{KOH}$, then softened in lactic acid in which a dash of lignin pink had been dissolved. Measurements were made using an ocular micrometer, and drawings were made with the aid of a camera lucida. Identification and terminology used in this report conforms mostly with that adopted by Yamaguti (1963) and Fryer (1982).

\footnotetext{
${ }^{1}$ Girls' College of Education, Zoology Department; Jeddah, Saudi Arabia

P. O. Box 100396, Jeddah 21311 / Fax 966 - 2-6228220

E. mail abomossab@yahoo.com

Received Feb. 14, 2007, Accepted March, 30, 2007
} 


\section{RESULTS AND DISCUSSION}

Redescription of Argulus japonicus Thiele, 1900 1-Adult female (Figs. 1 A,B and Figs,2.A-D ) .

Body dorsoventrally flattened; overall length 3.6-4.1 mm. Head fused with first thoracic segment (cephalothorax), covered with a horseshoe-shaped carapace, which is expanded on each side into a broad and bluntly rounded lobe. Carapace (including posterolateral lobes) comprising $75-80 \%$ of total body length; totally covering the third pair of swimming leg in dorsal view. Frontal region of carapace well delimited by pronounced anterolateral depressions. Compound eyes quite evident, located at a level where frontal region joins main portion of carapace. Ventral surface of frontal region and lateral lobes armed with numerous regularly arranged, sharply pointed spines. Dorsal surface of carapace smobth. Thorax with four distinct segments, each with a pair of biramous swimming legs; ventral surface ornamented with scales; dorsal sutface smooth. Abdomen 0.7-0.9 mm . long comprising 19-20 $\%$ of total length; longer than broad; posterior lobes with rounded points separated by sinus at half length of abdomen. Paired spherical spermathecae (S) situated in anterior region of abdomen (Fig. 2D).

First antennae $\left(\mathrm{A}_{1}\right)$ with four segments, first segment heavily sclerotized, second segment largest, bears a blunt knob anteriorly. Second antennae $\left(\mathrm{A}_{2}\right)$ with five segments, first and second segments forming the swollen basal portion; third, fourth and fifth segments each elongate. Postantennal spines (Pas) (one each side of body) prominent, robust and blunt (Fig. 2A).

Mandibles(M)dentiferous, partially visible in mouth tube(Mt). First maxillae $\left(\mathrm{M}_{1}\right)$ forming powerful cuplike suckers (sucking discs) typical of Argulus species. Second maxillae $\left(\mathrm{M}_{2}\right)$ with five segments, first segment robust, with three large and blunt posteroventral projections (Fig. 2B); second segment elongate; third to fifth segments narrower than second (Fig. 2C). Two paris of postmaxillary spines (PMs) present, the first (anterior) being rather stouter, located just medial to basal segment of second maxilla, the second located one on each side of midline just posterior to the first (Fig. 2B).

First to fourth pairs of swimming legs biramous with two segmented sympods; exopodite slightly longer than endopodite; rami bearing long plumose setae. Fourth legs each bearing natatory lobe (NL)(expanded portion of coxa) with dense border of pinnate setae (Fig. 2,D).

\section{2-Adult male (Figs. 3A,B):}

Overall length of single specimen examined $3.4 \mathrm{~mm}$. Similar to examined adult females except most notaboly as follows: male not as heavily pigmented as females, pigment spots slightly smaller than those of females and pigmentation most dense on lateral regions of carapace. Posterolateral lobes of carapace relatively shorter than those of females (Figs . 1A,3A). Carapace length 77.5\% of total body length. Abdomen length $0.6 \mathrm{~mm}$. Paired elliptical testes $(\mathrm{T})$, extending from anterior to posterior portion of abdomen (Fig. 3A). Sympods of third pair of legs modified possessing a posterior cuplike region. Sympods of fourth pair of legs modified at point opposing cuplike region of third legs (Fig. 3B). Natatory lobes of fourth legs with more pointed lateral ends than those of females (Figs. 1A ,3B).

Three Argulus spp. documented in Europe; A.japonicus, A.foliaceus and A.coregoni, occur on brown trout, as well as perch, tench, carp, pike and bream. These species, previously known as synonyms, were differentiated by Fryer (1982) according to length of body, posterior lobes of cephalothoracic carapace and posterior emargination of abdomen. Comparison with published descriptions and illustrations leaves no doubt that the specimen is Argulus japonicus. The overall shape of the body and of the abdomen, the extent to which the legs are covered or exposed by the carapace, the depth of the anal sinus, agree with the general descriptions of Wang (1958), Yamaguti (1963), Pilgrim (1967) and Fryer (1982). Differences in some body measurements may be due to individual or rather seasonal variations.

This study represents the first record of A. japonicus in Saudi Arabia.

\section{Pathology:}

General symptoms associated with Argulus japonicus infections included lack of appetite and abnormal swimming of the infected fishes. Skin irritation manifested by flicking of the fins and is often accompanied by increased mucous production over the skin surface with the a ppearance of small haemorrhages were also observed .In heavily infected fishes chronic inflammation develops, the infected surface of the integument ulcerate, the epithelium is destroyed and the dermis becomes exposed (Figs. 4A,B).

Similar symptoms have been noticed by Kabata (1970 ,1985 ) and Papema and Zwerner(1976) on different fishes infected with $A$.japonicus.These authors stated that Argulids infecting the skin and fins of fish induce several local damage to integument. Damage is caused by the piercing proboscis stylet which enters deep into the skin's dermal layer and secretes lytic and toxic substances resulting in acute haemorrhagic and inflamed wounds. Attachment to and crawling on the skin also causes irritation and abrasions leading first to proliferation and later to desquamation and erosion of the epithelium 

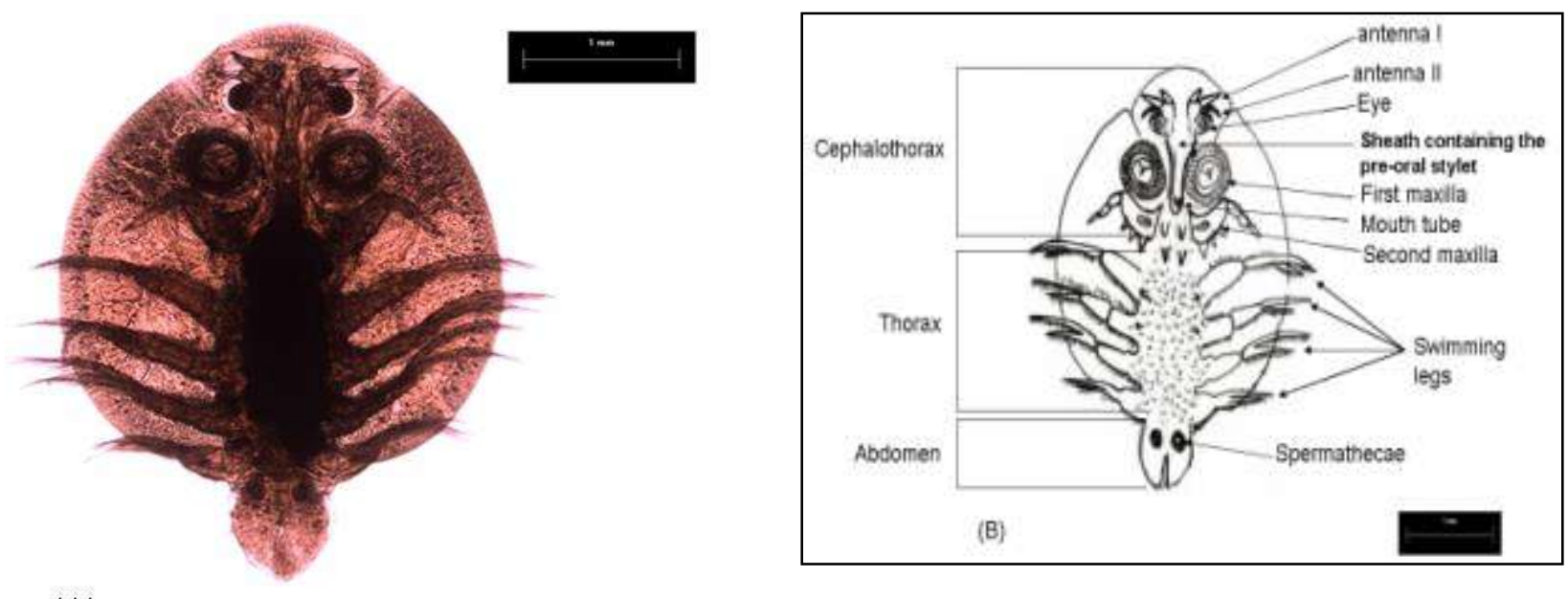

(A)

Figs. 1. (A and B): Adult female Argulus japonicus (A) Ventral photomicrograph (B) camera lucida drawing
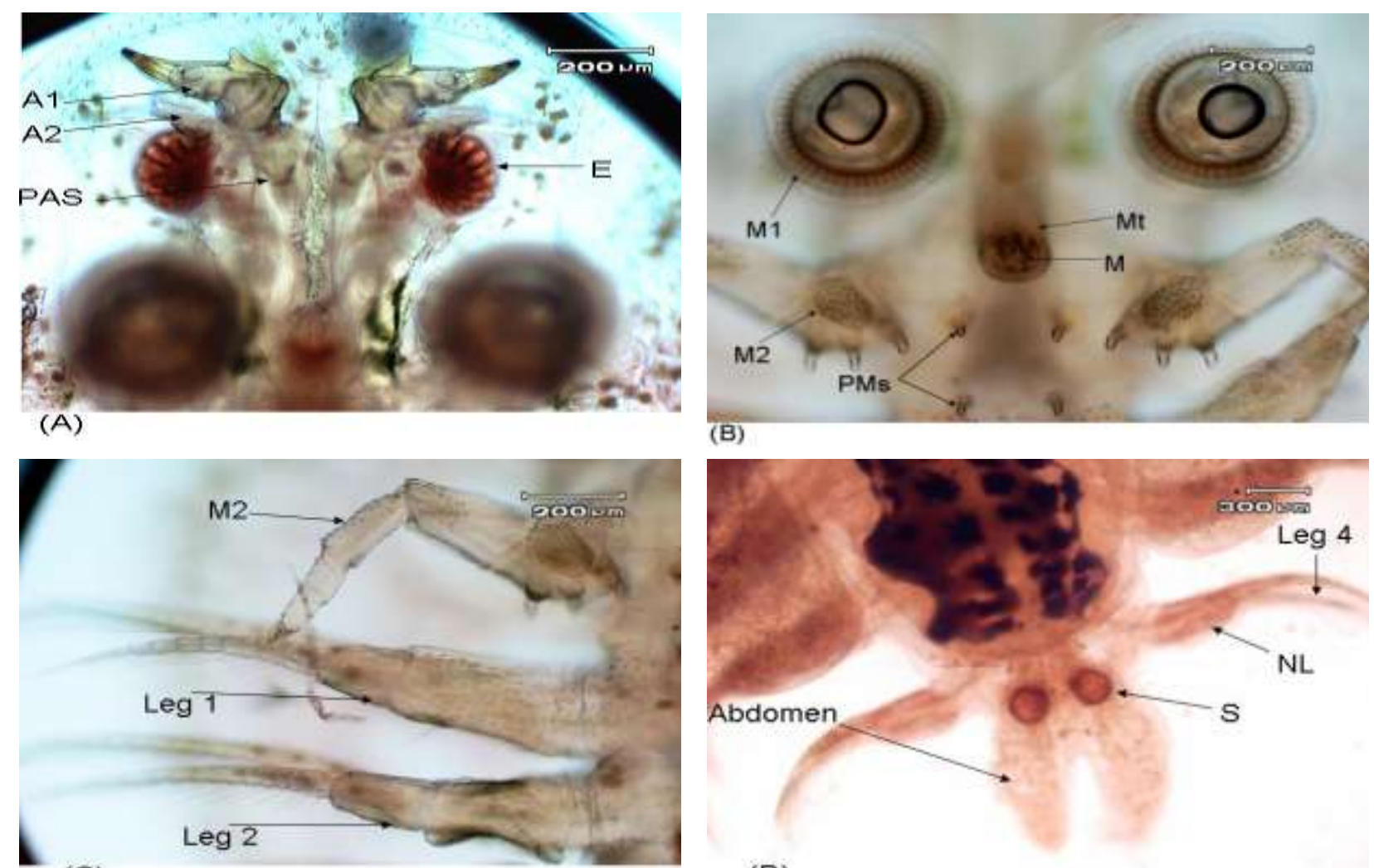

(C)

(D)

Figs. 2 (A-D): Photomicrographs of adult female Argulus japonicus.

Fig. 2(A): First $\left(A_{1}\right)$ and second $\left(A_{2}\right)$ antenna, post-antennal spine (P A S) and compound eye (E).

Fig. 2(B): First maxilla $\left(M_{1}\right)$ or suckers with supporting rods and sclerites, mouth tube (Mt) with mandibles $(\mathrm{M})$, base of second maxilla $\left(\mathrm{M}_{2}\right)$ and postmaxillary spines (PMS).

Fig. 2(C): Second maxilla $\left(M_{2}\right)$, First $\left(\operatorname{leg}_{1}\right)$ and second $\left(\operatorname{leg}_{2}\right)$ swimming leg.

Fig. 2(D): Posterior of female showing fourth swimming leg $\left(\operatorname{leg}_{4}\right)$ with natatory lobe (NL) and a bilobed abdomen with spherical spermthecae (S). 

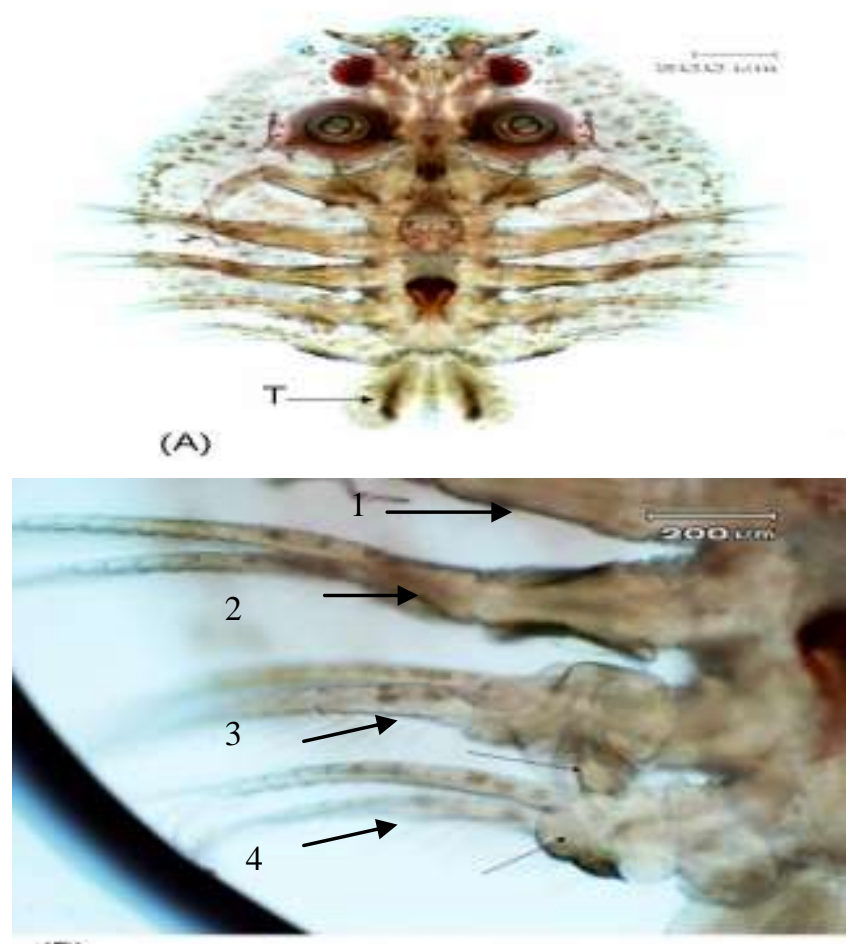

(B)

Figs. 3 (A and B): Photomicrographs of adult male Argulus japonicus.

Fig. (A): whole mount (ventral), note bilobed abdomen with long elliptical testes (T).

Fig. (B): swimming legs 1-4, arrows showing modification of third and fourth legs from those of female.

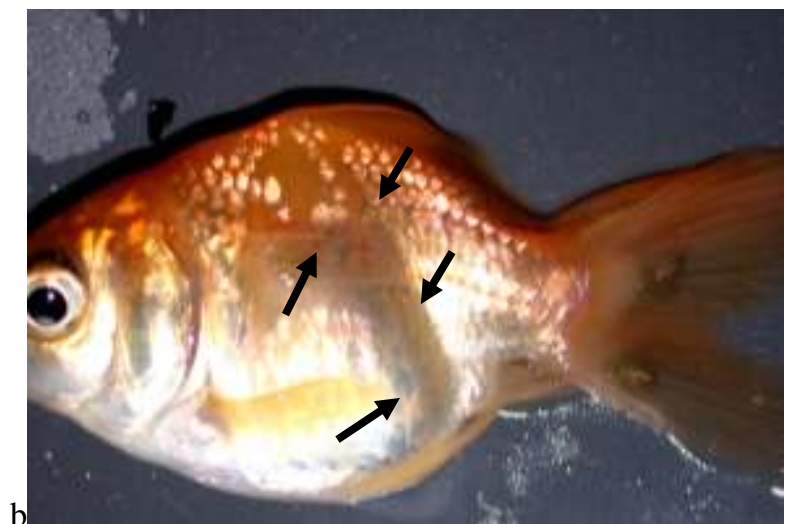

(B) of fish .

Fig. 4 B: Two specimens of A. japonicus can be seen attached to the anal fin of an infected gold fish. Arrows surround an area of epidermal desquamation.

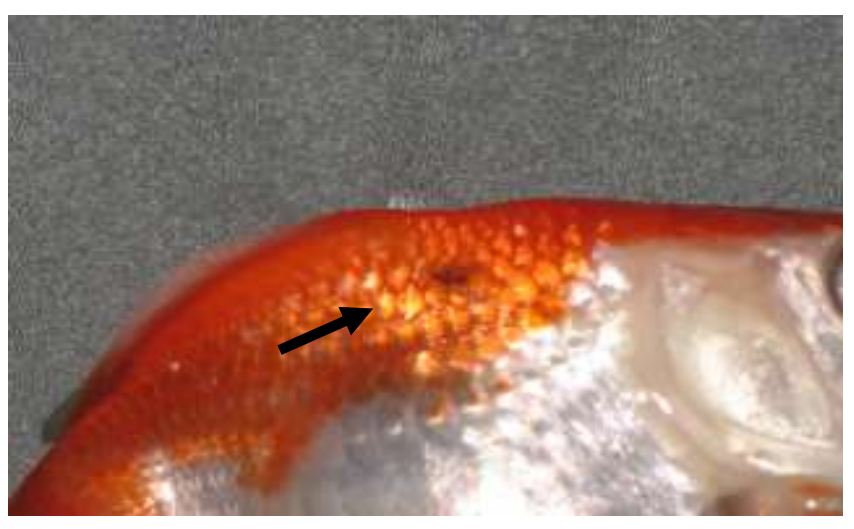

(A) 
Kabata (1985) stated that the Argulids form the majority of the Branchiuran group of parasites which have been described as economically important pathogens of finfish in temperate and tropical regions.

\section{REFERENCES}

Benz, G. W., Otting, R. L. and Case, A. (1995): Redescription of Argulus melanostictus (Branchiura:Argulidae), aparasite of California grunion (Leuresthes tenuis:Atherinidae), with notes regarding chemical control of A.melanostictus in a captive host population. Journal of Parasitology 81(5): 754-761.

Byrnes, T. (1985): Two new Argulus species (Branchiura:Argulidae) found on Australian bream (Acanthpagrus spp.). Australian Zoologist 2(7): 579-586.

Campbell, A. D. (1971): Argulus japonicus Thiele, 1900 (Crustacea: Branchiura) -A new record for New Zealand. N. Z. Journal of Marine and freshwater Rescarch 1: 395398.

Cressey, R. F. (1972): The genus Argulus (Crustacea:Branchiura) of the United States. Biota of freshwater Ecosystem, U. S. Environmental Protection Agency identification Manual 2: viii +1-4.

Cusack, R. and Cone, D. K. (1986): A review of parasites as Vectors of viral and Bacterial diseases of fish J. of Fish Diseases 9: 169-171.

Fryer, G. (1960): Studies on some parasitic Crustaceans on African freshwater fish, with a desription of a new copepod of the genus Ergasilus and a new branchiuran of the genus Chonopeltis. Proc. Zool. Soc. Lond., 133: 629647.

Fryer, G. (1968): The parasitic Crustacea of African freshwater fishes: their biology and distribution. Journal of Zoology, London 156(1): 45-95.

Fryer, G. (1982): The parasitic Copepoda and Branchiura of British freshwater fishes: Ahandbook and key Freshwater Biological Association. Scientific Publication. No: 46.
Heegaard, P. (1962): Parasitic Copepoda from Australian waters. Records of the Australian Museum 25: 149-234.

Hewitt, G. C. and Hine, P. M. (1972): Checklist of parasites of

New Zealand fishes and of their hosts. New Zealand Journal of Marine and freshwater Research 6 (1/2): 69-114.

Kabata, Z. (1970): Crustacea as enemies of fish. Book 1, Snieszko, S., Axelrod H. R. (ed.), Diseases of Fish, T. F. H. Publications, Jersey City, N. J.

Kabata, Z. (1985): Parasites and Diseases of Fish Culturedin the Tropics. Taylorand Francis.

Kruger, I.; Van As, J. G. and Saayman, J. E. (1983): Observation on the occurrence of the fish Iouse Argulus japonicus Thiele, 1900 in western Transvaal. South African Journal Zoology 18: 408-410.

Landsberg, J. H. (1989): Parasites and associated diseases of fish in warm water culture with special emphasis on intensification. In: Shilo, M. and Sarig, S. (ed.) Boca Raton, Flo. 1995-252.

Papema, L. and Zwerner, D. E. (1976): Parasites and diseases of striped bass, Morone saxatilis (Walbaum) from the lower chesapeake bay. Journal Fish Biology. 9: 267-287.

Papema, I. (1991): Diseases caused by parasites in the aquaculture of warm water fish. Annual. Rev. Fish Dis., 1: 155-194.

Pilgrim, R. L. C. (1967): Argulus Japonicus Thiele, 1900. (Crustacea: Branchiura) A new record for New Zealand N. Z. Journal of Marine and Fresh water Rescarch 1: 395398.

Richards, R. (1977): Diseases of aquarium fish-2. Skin diseases. Vet. Rec. 101: 132-135.

Wang, K. N. (1958): Preliminary studies on four species of Argulus parasitic on Fresh-water fishes taken from the area between Nanking and Shanghai with notes on the early larval development of Argulus chinensis. Acta Zool. Sin. 10(3): 322-340.

Yamaguti, S. (1963): Parasitic Copepoda and Branchiura of Fishes. Interscience Publishers, New York. 


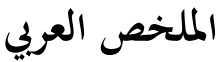

\section{إعادة وصف للنوع "أرجيولس جابونيكس " (كرستيشيا :برانكيورا ) طفيل خارجي على سمكة كاراسيس أوراتس. مع بعض الملاحظه المتعلقة بالناحية الأمراضية لها .}

$$
\text { فوزيه حسن طوله }
$$

$$
\begin{aligned}
& \text { تم فحص بعض مـن أسماك كاراسيس أورانس وهي مـ الأسماك التغذية. وقد جمعت الطفيليات من على الجلد والزعانف للأسماك }
\end{aligned}
$$

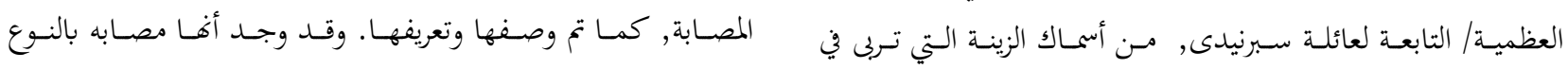

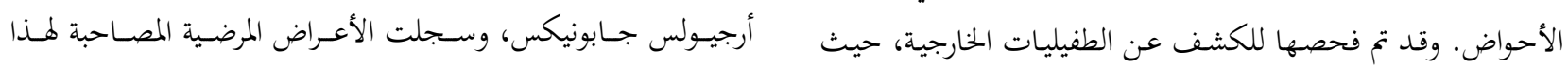

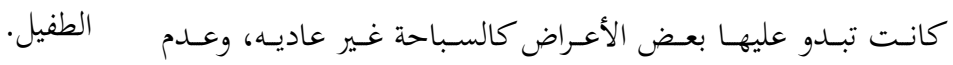

